\section{Screening Malus Seedlings for Cold Hardiness}

H.M. Mathers ${ }^{1}$

Department of Horticulture and Crop Science, Ohio State University, Columbus, OH 43210-1096

\section{Stushnoff}

Department of Horticulture, Colorado State University, Fort Collins, CO 80523-1173

Additional index words. winter hardiness, seedling acclimation, apple, Malus pumila 'Golden Delicious', M. baccata $\times$ M. pumila 'Antonovka' M. baccata $\times$ M. pumila 'Rescue', regrowth

\begin{abstract}
Twelve-week-old Malus seedlings were induced to cold harden by exposure to low temperature and freezing environments. The effectiveness of induced acclimation by exposure to stimuli such as low temperature $\left(3\right.$ to $\left.5^{\circ} \mathrm{C}\right)$, frequency of exposure to freezing temperatures $\left(-3^{\circ} \mathrm{C}\right)$, storage time before and after induction and the effects of different screening temperatures $\left(-20,-30\right.$, and $\left.-40^{\circ} \mathrm{C}\right)$ were investigated with seedlings grown in a greenhouse from open-pollinated 'Golden Delicious' apple (Malus pumila (Mill.), 'Antonovka' apple (M. baccata (L.) Borkh. $\times$ (M. pumila) and 'Rescue ' apple (M. baccata) $\times$ (M. pumila). Differentiation of the seedling populations with respect to cold hardiness was not achieved until after acclimation at cool temperatures $\left(3\right.$ to $\left.5^{\circ} \mathrm{C}\right)$ for 6 weeks. Further population differentiation was achieved by exposure to one or more frosts $\left(-3^{\circ} \mathrm{C}\right)$. Once the acclimation response had been initiated the seedlings could be held for up to 11 days, under the same conditions, with no significant decrease in hardiness. Hardiness levels of acclimated and nonacclimated open pollinated seedlings coincided with known inherent hardiness responses for all three maternal cultivars evaluated. A binomial form of regrowth data collection, percent seedling survival, was determined to be the most efficient and most precise measure of evaluation. Induction of cold hardiness in very young seedlings and the use of a controlled freeze testing protocol should facilitate rapid screening of large progenies and improve the rate of progress in breeding for cold hardiness.
\end{abstract}

Low temperature is the most important environmental stress limiting the diversity of Malus sp. and other woody plant taxa that can be grown in northern regions. At the whole plant level, resistance to cold is a complex quantitatively inherited character (Artlip et al., 1997; Cummins and Aldwinkle, 1983; Gelvonauskis et al., 2000; Stushnoff and Quamme, 1983). Fruit breeders have introduced a number of cold hardy cultivars; however, field screening of seedlings continues to be time consuming, costly, and subject to unpredictable and uncontrollable stress when selection for low temperature is left to chance in the form of test winters under natural conditions. Progress in breeding for improved cold resistance has been inhibited by the lack of a simple, reproducible

Received for publication 2 July 2003. Accepted for publication 10 May 2004. Salaries and research support provided by state and federal funds appropriated to the Ohio Agricultural Research and Development Center, The Ohio State University. Manuscript number HCS 02-24. We acknowledge the University of Saskatchewan College of Graduate Studies and Research and the Les Kerr Scholarship for the provision of graduate assistant funding for this research. We would also like to acknowledge the direction provided by R.J. Baker and R. St. Pierre as committee members and the technical assistance provided by H. Quamme, Rick Sawatzky, Marianne Tiessen-Bell, Laurie Friesen, Christine McOnie, Luke Case and James Beaver.

${ }^{1}$ Author to whom correspondence should be sent. seedling screening protocol to facilitate the evaluation of large progenies.

Because cold resistance is multigenic, the breeder must be able to screen very large numbers of progeny to select the individual with the optimum combination of genes (Allard, 1960). Of all breeding methods, mass selection at the seedling level is the simplest, the least expensive, and the most time efficient. A hybrid program must generate twice the amount of response per cycle to provide a rate of response equivalent to mass selection (Hansche, 1983). Seedling screening can reduce by $90 \%$ the number of trees, which normally need to be grown under field conditions for at least 10 years (Quamme and Stushnoff, 1983). Not much is known about the physiology of cold stress with young seedlings, but it has been shown that substantial cold hardiness can be induced as early as 10 to 12 weeks after seedling emergence and that the response appears to be related to the inherent hardiness of the seed source cultivar (Stushnoff et al., 1985). Lapins (1962) noted that the relative ranking of 1-year-old apple seedlings was similar to the adult phase, although the seedlings were slightly hardier. This observation suggests that suitable protocols could be developed to screen apple seedlings for cold hardiness.

The main objective of this study was to determine the effectiveness of controlled acclimation and to develop a protocol that could be used for screening 12 -week-old apple seedlings for cold hardiness. In the procedure presented in this paper, cold hardiness was screened by mass selection, and individual seedlings were selected on the basis of their phenotypic response to cold stress. We studied the influence of cold temperature acclimation $\left(3\right.$ to $5^{\circ} \mathrm{C}$ ) and the response to one or more exposures of frost $\left(-3^{\circ} \mathrm{C}\right)$. The optimum freezing test temperature at which to screen, the response of seedlings to storage before and after acclimation, and the determination of an appropriate evaluation method to assess progeny response were evaluated.

This experiment was designed to use six of Quamme and Stushnoff's (1983) nine outlined steps useful in breeding for cold hardiness in fruit crops. All six proposed steps were achieved: 1) the ability to survive temperatures as low as $-40{ }^{\circ} \mathrm{C}$ was addressed as the major problem; 2) a determination was made of the environmental controls influencing acclimation; 3) an appropriate pre-conditioning routine was developed for standardized testing; 4) a controlled freezing procedure with a standardized freezing and thawing rate was developed; 5) an appropriate viability test was outlined; and, 6) 12-week-old seedlings were used to facilitate rapid progress in the breeding program.

\section{Materials and Methods}

Open-pollinated seedlings were grown from three cultivars selected based on distinct differences in response to survival at low temperatures. The most cold hardy seed cultivar was Malus baccata (L.) Borkh. $\times$ M. pumila (Mill.) 'Rescue', grown at Saskatoon, SK, Canada where the pollen parent was adapted to the region's harsh winters. The city of Saskatoon ( $52^{\circ} 07^{\prime} \mathrm{N}$ Latitude, $106^{\circ} 40^{\prime} \mathrm{W}$ Longitude) lies within Canadian plant hardiness $(\mathrm{CPH})$ zone $2 \mathrm{~b}$. The length of the frost-free season is 108 d (St. Pierre, 1995). The December through February mean minimum temperature is -20.7 ${ }^{\circ} \mathrm{C}$ and the extreme minimum is $-50{ }^{\circ} \mathrm{C}$ (St. Pierre, 1995). Seeds of the intermediately hardy cultivar 'Antonovka' (CPH zone 3) (Rayment, 2003) (Malus baccata $\times$ M. pumila) were obtained from Summerland, British Columbia, Canada where the pollen parent was presumably adapted to Summerland's climate and less cold hardy. Summerland (49³4' N Latitude, $119^{\circ} 39^{\prime}$ W Longitude) lies within Canadian plant hardiness zone 6 . The December through February mean minimum temperature is -4.2 ${ }^{\circ} \mathrm{C}$ and the extreme minimum is $-28.7^{\circ} \mathrm{C}$ (Environment Canada, 2003). Seeds of the cold tender ( $\mathrm{CPH}$ zone 6) cultivar 'Golden Delicious' $M$. domestica (Ontario Ministry of Agriculture and Food, 2001) were derived from commercially grown fruit obtained from British Columbia, Canada, that in all probability were pollinated by a cold tender (CPH zone 6 ) cultivar in a commercial orchard.

In late September, the fruit of Rescue and Golden Delicious cultivars were cut open and the seeds were removed and immersed in water to loosen particles of fruit clinging to the seeds. The seeds were then dried on paper towels for $24 \mathrm{~h}$. Dried seed of 'Antonovka' was obtained 
from Summerland, BC later in September. All dried seed was then stored in a $6{ }^{\circ} \mathrm{C}$ cooler for 1 month then soaked in water for $24 \mathrm{~h}$ before stratification. Seeds were stratified in plastic bags containing moist quartz sand and a small quantity, 5.6 (product) oz/ $0.45 \mathrm{lb}$ of sand [0.2 (product) $\mathrm{g} \cdot \mathrm{kg}^{-1}$ of sand] of captan, N-Trichloromethylthio-4-cyclohexene-1,2-dicarboximide (Captan 50; Micro Flo Co., Memphis, Tenn.) at 3 to $5{ }^{\circ} \mathrm{C}$, for 9 weeks. At the first sign of radicle emergence, seeds were planted in a mixture of 1 Canadian sphagnum peat : 1 perlite : 1 medium grade vermiculite in Styro seedling trays ( 130 cells/tray) (Beaver Plastics Ltd., Edmonton, AB, Canada). Planting at the start of radicle emergence provided uniform seedling heights for subsequent treatments. Plants were maintained in a greenhouse at 20 to $30{ }^{\circ} \mathrm{C}$ with supplemental light (Sylvania Gro-Lux and cool-white fluorescent tubes, $900 \mu \mathrm{mol} \cdot \mathrm{m}^{-2} \cdot \mathrm{s}^{-1}$ at 10 to $15 \mathrm{~cm}$ from canopy, $16 \mathrm{~h} \cdot \mathrm{d})$ and provided twice a week with $20 \mathrm{~N}$ 8.8P-16.6K (20-20-20) (Peter Professional, The Scotts Co., Marysville, Ohio), $\left(1.9 \mathrm{~g} \cdot \mathrm{L}^{-1}\right.$ per tray) for 6 weeks until they were 5 to $7 \mathrm{~cm}$ tall. Fertility and moisture were kept at levels during the entire 6-week growing period to minimize stress factors other than those imposed by the cold treatments. The study consisted of three experiments: 1) a freeze test for response of nonacclimated seedlings; 2) a freeze test for response of acclimated seedlings, and 3) a freeze test for response of seedlings to storage at cool temperatures before and after frost acclimation. Due to space limitations, for all three experiments only three trays could be frozen in the computerized freezer at one time.

Experiment 1: Response of nonacclimated seedlings. Six-week-old plants of all three cultivars were grown for an additional 6 weeks in a greenhouse under the same conditions as described above. In all experiments, each trays were covered with a $0.5-\mathrm{cm}$-thick layer of moist peat, before freeze tests and placed in a box made of insulating Styrofoam $2.54 \mathrm{~cm}$ thick. Each tray consisted of 90 centers. Two rows around the outside of each tray, totaling 60 centers, were filled with medium only to act as insulation during the freeze. The inside 30 centers were seeded. Plants were frozen in a converted (Mathers et al., 1991) freezer (U1tralow Revco; Revco Scientific Inc., Asheville, N.C.) in two stages with a controller (Micron 82300; Research Inc., Minneapolis, Minn.). The two stages of freezing were a holding period at $-3{ }^{\circ} \mathrm{C}$ for $10 \mathrm{~h}$ then a temperature drop period of $2{ }^{\circ} \mathrm{C} / \mathrm{h}$ to $-5,-10$, or $-15^{\circ} \mathrm{C}$. The seedlings were given no acclimation preconditioning. After freezing treatments were complete, plants were thawed and assessed for hardiness using the three viability tests described below.

The experiment was replicated four times between May and July, with 10 subsamples per treatment, cultivar and replication. A randomized complete block design with freezing used as a blocking factor, a staggered planting schedule for each replication was used to ensure all seedlings were the same age when exposed to the freezing treatments.

Experiment 2: Response of acclimated seedlings. Six-week-old seedlings of each cultivar were grown in a controlled temperature chamber for 6 weeks at cool temperatures (3 to $5{ }^{\circ} \mathrm{C}$ ) with supplemental light (Sylvania Gro-Lux and cool-white fluorescent tubes, 600 $\mu \mathrm{mol} \cdot \mathrm{m}^{-2} \cdot \mathrm{s}^{-1}$ at 5 to $10 \mathrm{~cm}$ from the canopy, $\left.8 \mathrm{~h} \cdot \mathrm{d}^{-1}\right)$. Further acclimation was induced by subjecting the plants to one to six frost $\left(-3^{\circ} \mathrm{C}\right.$, $16 \mathrm{~h}$ ) events in a computerized freezer. Between frost treatments, plants were warmed at 3 to 5 ${ }^{\circ} \mathrm{C}$ for $32 \mathrm{~h}$ to enable complete thawing of the potting media. In Expt. 2, each tray consisted of 130 centers with the two outer rows of cells in the tray containing only potting media, totalling 76 centers, to act as insulation during the freeze. The inside 54 centers were seeded. The trays were covered with peat and placed in a Styrofoam box as outlined in Expt. 1. Plants were frozen in an Ultralow Revco freezer as described above in three stages. The three stages of freezing were a holding period at $-3{ }^{\circ} \mathrm{C}$ for $10 \mathrm{~h}$, a temperature drop period of $2{ }^{\circ} \mathrm{C} / \mathrm{h}$ to $-16{ }^{\circ} \mathrm{C}$, and a temperature drop of $4{ }^{\circ} \mathrm{C} / \mathrm{h}$ to the desired temperature, $-20,-30$, or $-40{ }^{\circ} \mathrm{C}$. After freezing treatments were complete, plants were thawed and assessed for hardiness using the three viability tests described below.

The experiment was replicated four times between September to September with 18 subsamples per experimental unit. A randomized complete block design, blocking on freezing was used. A staggered planting schedule for each replication was used to ensure all seedlings were the same age when exposed to the freezing treatments.

Experiment 3: Response to storage. Sixweek-old seedlings of each cultivar were grown in a controlled temperature chamber for 6 weeks at cool temperatures $\left(3\right.$ to $\left.5^{\circ} \mathrm{C}\right)$ with supplemental light (Sylvania Gro-Lux and cool-white fluorescent tubes, $600 \mu \mathrm{mol} \cdot \mathrm{m}^{-2} \cdot \mathrm{s}^{-1}$ at 5 to $10 \mathrm{~cm}$ from the canopy, $8 \mathrm{~h} \cdot \mathrm{d}^{-1}$ ) to acclimate. Acclimated seedlings were held either an additional $11 \mathrm{~d}$ in the 3 to $5{ }^{\circ} \mathrm{C}$ chamber, described above without a frost treatment, or 10 days and given one frost exposure before the freeze tests. The two storage treatments were thus characterized as 0 plus $11 \mathrm{~d}$ in the cooler, and one frost plus $10 \mathrm{~d}$ in the cooler. Plants were frozen as described in Expt. 2 to $-20,-30$, and $-40{ }^{\circ} \mathrm{C}$. After freezing treatments were complete, plants were thawed and assessed for hardiness using the three viability tests described below. The experiment was replicated four times between August to October with 18 subsamples per experimental unit. A randomized complete block design, blocking on freezing was used. A staggered planting schedule for each replication was used to ensure all seedlings were the same age when exposed to the freezing treatments.

Viability tests. When the freezing cycle was completed, the seedlings were held at 3 to 5 ${ }^{\circ} \mathrm{C}$ overnight to permit gradual thawing then moved to the greenhouse, defoliated with scissors, and regrown for 4 weeks. Plant viability was measured at the end of the 4 weeks in three ways: percent seedling survival, percent bud survival, and a score of viable growth. Percent seedling survival was collected as binomial data with each plant given a rating of either 1 or 0 . Only completely dead plants were recorded as 0 . Percentages of plant population survival were then calculated by dividing the number of plants given a rating of one over the total number of seedlings per tray per cultivar population. Percent bud survival was also collected as binomial data by rating buds as either dead or alive. Percentages of bud survival were calculated by dividing the number of live buds by the total number of buds per plant. Percent bud survival for each experimental unit was calculated as the average of percent bud survival of 18 seedlings in Expt. 2 and 3 and 10 seedlings in Expt. 1. Viable growth was scored on a range of 1 to 100 . Each seedling was scored by visual comparison of the amount of green stem to the total height of original growth before the freeze. Mean scores for up to 18 plants, for Expts. 2 and 3 and 10 seedlings in Expt. 1, were used as the viable growth scores of individual experimental units (Mathers, 1988).

Statistical analysis and data transformation. Analyses of variance was conducted (SAS procedure General Linear Model(GLM), (SAS Institute Inc., Cary, N.C.) on the calculated means of the 18 plants in each tray for all three measures (percent seedling survival, percent bud survival, and viable growth score) in Expts. 2 and 3 and 10 plants in Expt. 1. Fisher's least significance difference test were used to compare means of treatments (SAS Institute Inc.). The Type IIII Sum of Squares analyses was performed and graphs were produced in Excel from the analyses. All factors were considered fixed effects; therefore all terms were tested for significance against the error mean square. In the case of significant frost effects, orthogonal comparisons were used to compare means. Since all the data was expressed in percentages, an arc sine of square root transformation was conducted on all three sets: percent seedling survival data, percent bud survival data, and viable growth score data (Steel and Torrie 1980). The data sets were reanalyzed, and the two analyses for each regrowth measure were compared. The analyses of variance of the transformed data indicated the same significant differences as displayed in the nontransformed data analysis (data not shown). For simplicity only the nontransformed data is presented.

\section{Results and Discussion}

Experiment 1: Response of nonacclimated seedlings. Nonacclimated seedlings did not cold harden and were injured at relatively moderate freeze-test temperatures (Fig. 1). All cultivars responded in a similar manner to the different freeze-test temperatures (data not shown), therefore, it was not possible to differentiate between different cultivars in the nonhardy condition. The main effect of temperature was significant (Fig. 1). Seedling survival at $-5^{\circ} \mathrm{C}$ was greater than at -10 and $-15^{\circ} \mathrm{C}$, and survival at $-10^{\circ} \mathrm{C}$ was greater than at $-15^{\circ} \mathrm{C} . \mathrm{LT}_{50}$ values (temperatures at which $50 \%$ of the seedlings were killed) summed over all cultivars occurred at $-7^{\circ} \mathrm{C}$. 
Magness (1929) reported that nonacclimated apple trees were killed by temperatures as high as $-7^{\circ} \mathrm{C}$. In spite of the fact that adult apple trees must attain vegetative maturity before they can be cold hardened (Friesen and Stushnoff, 1989), 12-week-old seedlings were hardened to as low as $-40^{\circ} \mathrm{C}$ (Mathers 1988). It is unknown if these seedlings passed through a physiological stage similar to vegetative maturity or if they simply possess a capability to perceive inductive signals to cold harden as an evolutionary adaptive mechanism that is unique to young seedlings. Gusta et al. (1983) hypothesized that since secondary thickening must be present in the cell walls for supercooling to occur, as it does in adult apple wood, it is probable that no supercooling occurs in 12-week-old apple seedlings. The mechanism of stress resistance shown in our freeze test of nonacclimated plants is probably a tolerance mechanism and possibly is best developed in the hardiest seed sources.

Holubolwicz and Pieniazek (1976) also conducted studies on the acclimation of apple seedlings and found that 8-month-old seedlings acclimated best at temperatures of $0{ }^{\circ} \mathrm{C}$ and immediate transfer to temperatures of -5 and $-10{ }^{\circ} \mathrm{C}$ killed the seedlings. Fuchigami et al. (1982) derived a model, which classified the process of hardening into two stages. The first stage was dependent on short-day induction at warm temperatures. The second stage was dependent on exposure to low temperatures near or at $0^{\circ} \mathrm{C}$ (Fuchigami et al. 1982). Holubowicz and Pieniazek (1976) presented data consistent with the acclimation model of Fuchigami et al. (1982). In our study, without exposure to short days and cool temperatures, cultivar seedlings were hardy to about $-7{ }^{\circ} \mathrm{C}$, concurring with Magness (1929). In subsequent experiments, it would be of interest to study the effect of ambient temperatures during short-day exposures to determine the difference in survival between southern and northern ecotypes with different acclimation regimes.

Experiment 2: Response of acclimated seedlings. Less than $5 \%$ of the total population survived a freezing temperature of $-40{ }^{\circ} \mathrm{C}$ (Fig. 2). Of the acclimated seedlings, $87 \%$ averaged over the three cultivars and frosts survived a freezing temperature of $-20^{\circ} \mathrm{C}$ (Fig. 2). More seedlings survived from the hardiest cultivar seed source 'Rescue' than from 'Antonovka' and 'Golden Delicious' (Fig. 2). However, this was only after exposure to frost $\left(-3^{\circ} \mathrm{C}\right.$ for $\left.16 \mathrm{~h}\right)$. At $-40^{\circ} \mathrm{C}$, only 2.1 and $1.6 \%$ of seedlings from 'Antonovka' and 'Golden Delicious' survived, respectively, compared to $20 \%$ survival for the 'Rescue' seedlings (Fig. 2). If we assume that a screening temperature approaching the temperature $\left(\mathrm{LT}_{50}\right)$ represents one credible target, then the temperature that best differentiated $50 \%$ of the hardiest seedlings in the overall population was between -20 and $-30{ }^{\circ} \mathrm{C}$. However, for the hardiest cultivar, 'Rescue', a screening temperature of $-30^{\circ} \mathrm{C}$ is too high. A freeze temperature below $-30^{\circ} \mathrm{C}$ would be more effective. On the other hand, seedlings from the less hardy cultivars, 'Antonovka' and 'Golden Delicious', could best be screened at about $-25^{\circ} \mathrm{C}$. This suggests that each cultivar has an optimum $\mathrm{LT}_{50}$ screening temperature but only after exposure to at least one frost. Without frost exposure all three cultivars had $<50 \%$ survival, Rescue (40\%), Antonovka (22\%) and Golden Delicious (17\%) (Fig. 3).

Strang and Stushnoff (1975) classified hardiness of apple cultivars based on their survival in different hardiness zones. Cultivar hardiness was based on the northern-most area

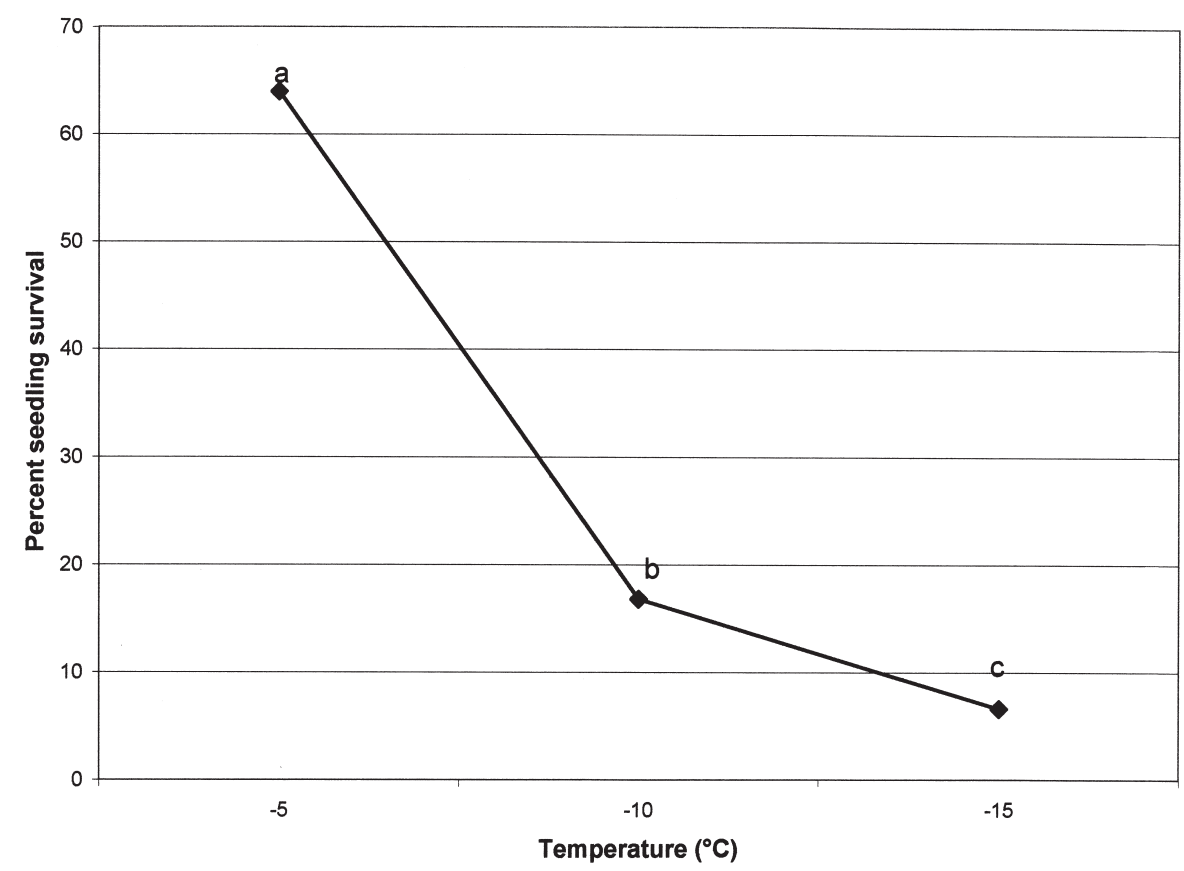

Fig. 1. Survival of nonacclimated seedlings in Expt. 1 pooled over three cultivars frozen to three test temperatures. Values followed by different letters are significantly different (Fisher's least significant difference (LSD) $P=0.05$ ). Each data point is the mean of 120 seedlings.

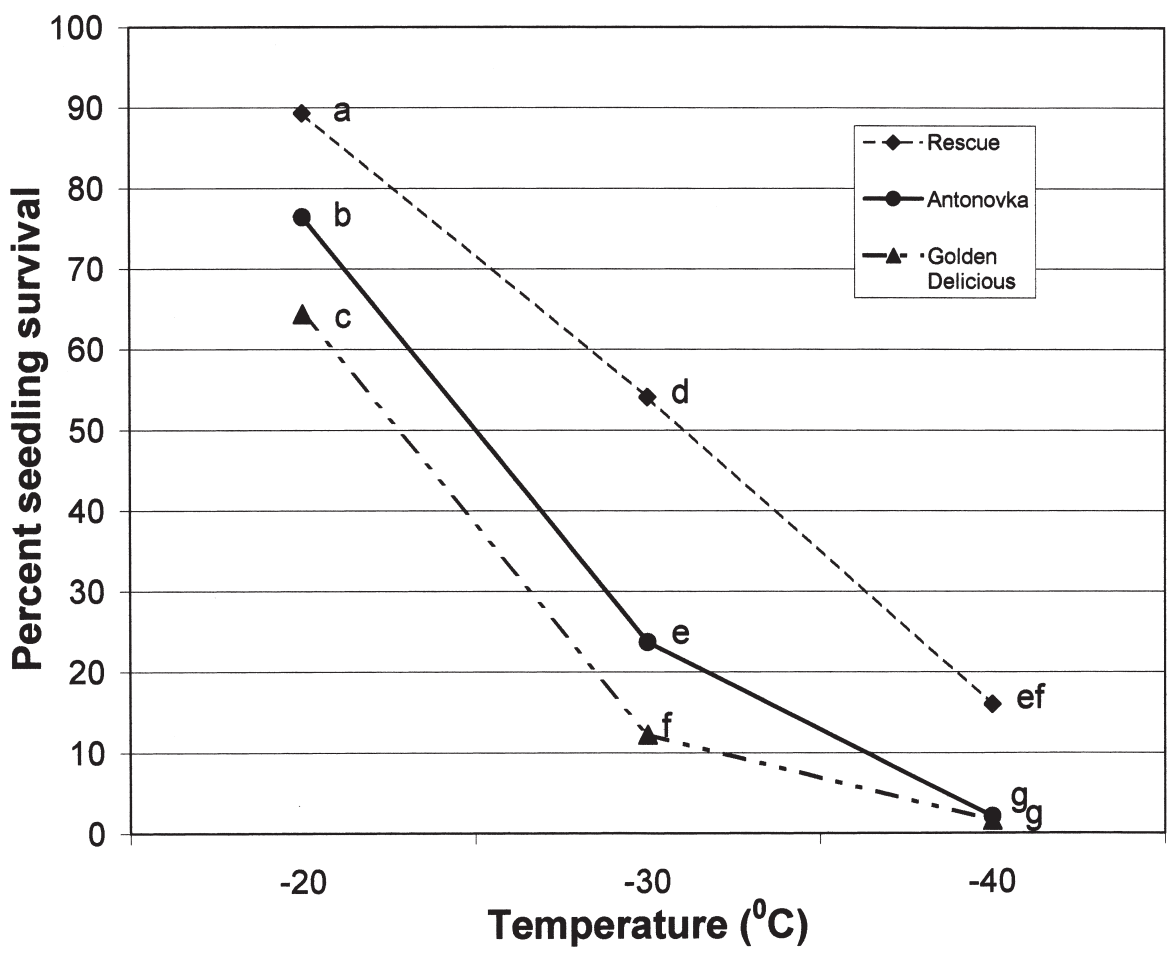

Fig. 2. Survival of open-pollinated seedlings from three apple cultivars following controlled acclimation in Expt. $2\left(3\right.$ to $\left.5^{\circ} \mathrm{C}\right)$ and freezing to three test temperatures and pooled over frost exposure. Values followed by different letters are significantly different (Fisher's least significant difference (LSD) $P=0.05$ ). Each data point is the mean of 432 seedlings pooled across six frost treatments and four replications. 


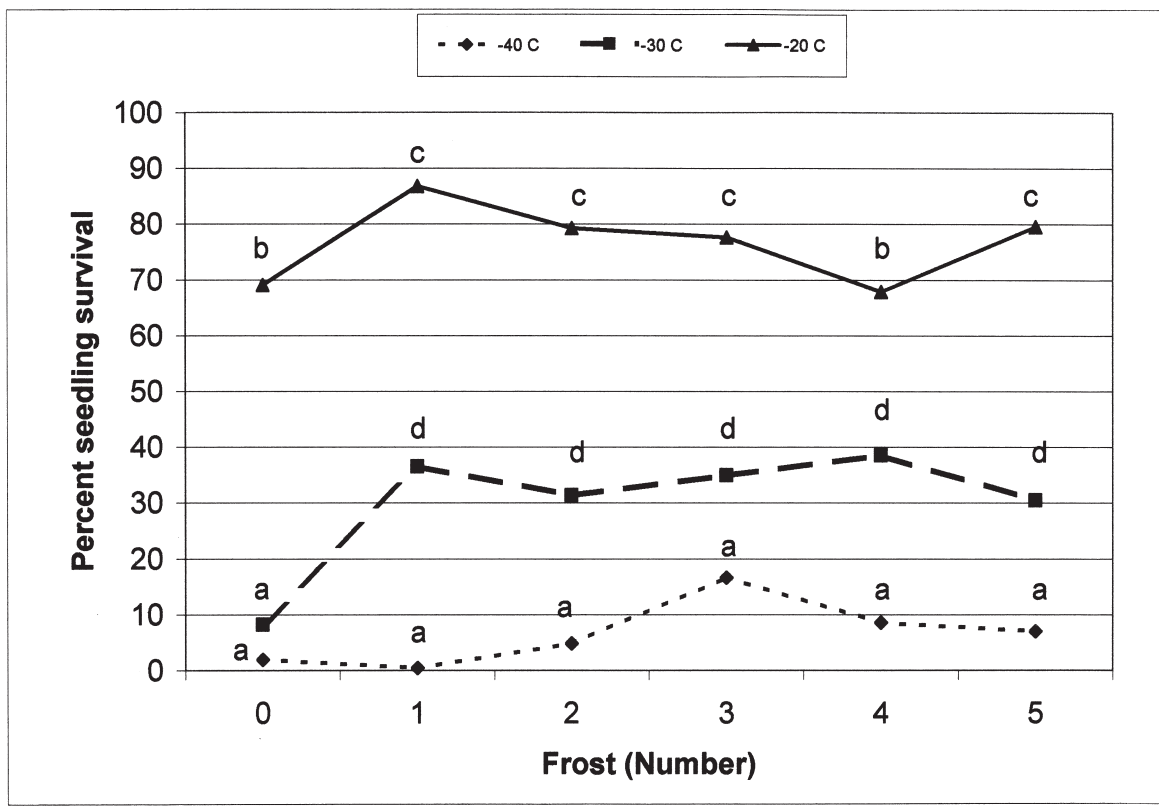

Fig. 3. Survival of open pollinated seedlings, averaged over three seed sources, frozen to three test temperatures following controlled acclimation in Expt. $2\left(3\right.$ to $\left.5{ }^{\circ} \mathrm{C}\right)$ and frost $\left(-3{ }^{\circ} \mathrm{C}\right.$ for $\left.16 \mathrm{~h}\right)$. Each data point is the mean of 216 seedlings from three cultivars. The residual of the orthogonal contrast, used to compare frost treatment means, indicates the significance of frost effects was due to the difference between no frost and one or more frosts. Values followed by different letters are significantly different (Fisher's least significant difference (LSD) $P=0.05$ ). Each data point is the mean of 216 seedlings from three freeze treatments and four replications.

Table 1. Analysis of variance results for Expt. 2, response of acclimated seedlings for percent seedling survival data.

\begin{tabular}{lcrr}
\hline Source of variation & df & MS & \multicolumn{1}{c}{ F } \\
\hline Replication & 3 & 5276 & $16.97^{* *}$ \\
Cultivar seedlings (C) & 2 & 13904 & $44.71^{* *}$ \\
Freeze temperature (T) & 2 & 91815 & $295.24^{* *}$ \\
Frost treatment (F) & 5 & 1233 & $3.96^{* *}$ \\
Frost vs. others & $(1)$ & 5552 & $17.85^{* *}$ \\
Residual & $(4)$ & 153 & $0.49^{\mathrm{NS}}$ \\
$\mathrm{T} \times \mathrm{F}$ & 10 & 626 & $2.01^{*}$ \\
$\mathrm{C} \times \mathrm{T}$ & 4 & 1327 & $4.27^{* *}$ \\
$\mathrm{C} \times \mathrm{F}$ & 10 & 215 & $0.69^{\mathrm{NS}}$ \\
$\mathrm{C} \times \mathrm{T} \times \mathrm{F}$ & 20 & 400 & $1.09^{\mathrm{NS}}$ \\
Error & 159 & 311 & \\
\hline
\end{tabular}

**** Significant at $P=0.05$ and 0.01 , respectively.

plants that were not exposed to any frost cycles; however, additional frost exposures did not result in increased hardiness over all cultivars (Fig. 3). The residual of the orthogonal contrast is very small indicating that the significance of the frost effects was due to the difference between no frost and one or more frosts (Table 1). One frost significantly increased the cold survival of all three cultivar seedlings. The relative increase, however, was different for each. One or more frosts with 'Rescue' gave a 74\% increase in survival over no frost exposures. 'Antonovka' responded with a $62 \%$ increase in survival and 'Golden Delicious' with an increase of $51 \%$ over zero frosts (data not shown). Guak and Fuchigami (2001) speculated that short days and low temperatures or frosts regulate different and independent endogenous acclimation processes and our findings concur with this observation.

Freezing-test temperature significantly influenced seedling survival (Table 1). Pooled over frost treatments, overall percent seedling survival decreased as the screening temperatures decreased (Fig. 2). Seedling survival of
$2{ }^{\circ} \mathrm{C}$, after a period of exposure to short days and cool temperatures, increased the hardiness levels of both 'Dolgo' and 'Golden Delicious' seedling populations. The increase in survival was more pronounced for the 'Dolgo' seedlings compared to the less hardy seedlings from 'Golden Delicious' (Stushnoff et al. 1985). This work also concurs with Ketchie (1985) findings that $-4{ }^{\circ} \mathrm{C}$ was the optimum temperature for acclimation of the xylem and bark after vegetative maturity (VM). Until VM was reached, by exposure to short days and temperatures just above freezing, trees did not acclimate to their full potential regardless of the temperature of exposure (Ketchie, 1985). A 7-d exposure to temperatures of 0 to $-5^{\circ} \mathrm{C}$ after VM was sufficient to maximize acclimation in apple (Ketchie 1985).

The nonsignificant cultivar $\times$ frost interaction (Table 1) suggests that the acclimated seedlings from all three cultivars responded in a similar manner to the frequency of frost treatments. The analysis of variance for percent bud survival and viable growth score (data not shown) showed similar significant differences as found by ANOVA of percent seedling survival data (Table 1), with one exception. The temperature $\times$ frost interaction was only significant for percent seedling survival. Since the percent seedling survival analysis indicates a significant interaction and the percent bud survival and viable growth score data does not, the percent seedling survival analysis is considered more sensitive. One possible explanation for this finding might be the relationship between small bud volumes and lack of low temperature exotherm (LTE) occurrence reported by Kadir and Proebsting (1994). They found that Prunus species with small buds had low water contents and lacked exotherms in December and January after 2 $\mathrm{d}$ at $-7{ }^{\circ} \mathrm{C}$. From this work we can infer that bud survival may be a less accurate measure of viability for the plant than overall tissue survival. Percent seedling survival is also a less time consuming measure of hardiness than determining bud survival or growth vitality. Data collection in the form of binomial values for percent seedling survival was determined to be the simplest, most efficient and most precise measure of cold hardiness.

Although our screening protocol on 12week-old Malus seedlings differentiated between progeny from cultivars of different hardiness levels, field evaluation of adult trees in the fruiting stage is also still essential and part of a breeding program for cold tolerance. For instance, a small planting at Saskatoon, SK (unpublished) contained 60 open-pollinated 'Dolgo' and 'Golden Delicious' Malus seedlings were screened to -40 and $-25^{\circ} \mathrm{C}$, respectively, with a protocol similar to the one we describe. In the field evaluation, all of the screened progeny from 'Dolgo' survived while all the screened progeny from the 'Golden Delicious' perished after the fifth winter.

Experiment 3: Response to storage. 'Rescue' seedlings that had been acclimated at 3 to $5{ }^{\circ} \mathrm{C}$ and held an additional $11 \mathrm{~d}$ at 3 to $5{ }^{\circ} \mathrm{C}$ did not change significantly in hardiness, $40 \%$ versus $43 \%$ survival (Fig. 4). Also, there was 


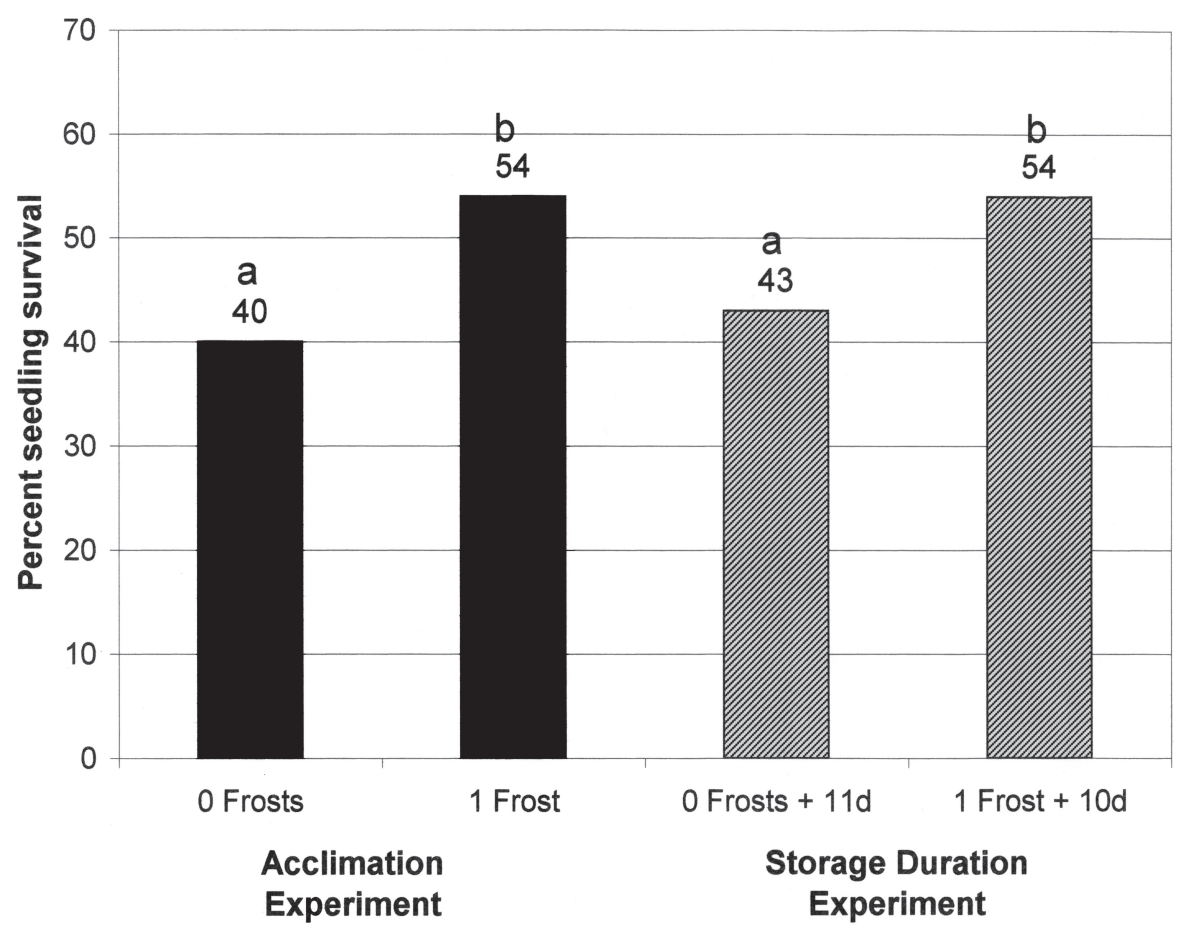

Fig. 4. Comparison of percent seedling survival data for 'Rescue' in Expt. 3, response to storage at 3 to $5^{\circ} \mathrm{C}$ for 11 or $10 \mathrm{~d}$ and after one or no frost treatments $\left(-3{ }^{\circ} \mathrm{C}\right.$ for $16 \mathrm{~h}$, followed by warming at 3 to $5{ }^{\circ} \mathrm{C}$ for $32 \mathrm{~h}$ ). Each data point is the mean of 216 seedlings. Values followed by different letters are significantly different (Fisher's least significant difference (LSD) $P=0.05$ ).

no change in hardiness when seedlings were held at 3 to $5^{\circ} \mathrm{C}$ for $10 \mathrm{~d}$ after a frost exposure. In this case the average survival was $54 \%$ for both treatments (Fig. 4). The response to storage was similar for the other two cultivars (data not shown). Once acclimated at 3 to 5 ${ }^{\circ} \mathrm{C}$, holding for an additional $11 \mathrm{~d}$ at 3 to $5{ }^{\circ} \mathrm{C}$ did not significantly change their hardiness (data not shown).

Storage for up to $10 \mathrm{~d}$ could follow the frost exposure without a significant reduction in cold survival. In addition, up to $11 \mathrm{~d}$ could elapse after the 6-week period in the cooler, before the frost treatment was applied, with no significant decrease in the hardiness response. A comparison of the 0 frost treatment response and the 0 frost $+11 \mathrm{~d}$ treatment (Fig. 4) illustrates this effect. These results greatly lessen the time pressure on the researcher permitting more flexibility to process large populations of progeny.

\section{Conclusions}

Plant survival, bud survival and growth viability tests can be used to screen for cold tolerance in apple; however, data collection in the form of binomial values for percent seedling survival appears to be the simplest, most efficient and most precise measure of cold hardiness. Screening must be done with cold-acclimated plants, not nonacclimated plants. Differentiation in hardiness response of the seedling populations was not achieved until after exposure to short days at cool temperatures for 6 weeks. Further population differentiation was achieved by exposure to one or more frosts compared to no frost ex- posures. Hardiness levels of acclimated and nonacclimated seedlings agreed with known inherent hardiness responses for all three cultivars evaluated. For crosses representing a full range of cold hardiness capabilities, a screening temperature close to $-30{ }^{\circ} \mathrm{C}$ would be most effective.

Screening seedlings of Malus, 12 weeks after emergence, using a protcol to induce acclimation and select the hardiest individuals could improve the efficiency of breeding for cold hardiness by eliminating a large proportion of cold-tender seedlings before time and maintenance costs are invested in field plantings. At this point, however, it is uncertain if undesirable linkages might also be selected by this process, but probably no more so than with field screening. Also, evaluation of adult trees in the fruiting stage is still essential to determine if the induction of hardiness in the seedlings become adult trees.

\section{Literature Cited}

Allard, R.W. 1960. Principles of plant breeding. John Wiley and Sons, New York.

Artlip, S., A.M. Callahan, C.L. Bassett, and M.E. Wisniewski. 1997. Seasonal expression of a dehydrin gene in sibling deciduous and evergreen genotypes of peach (Prunus persica [L.]Batsch). Plant Mol. Biol. 33:61-70.

Cummins, J.N. and H.S. Aldwinkle. 1983. Apple rootstock breeding, p. 294-394. In: J. Janick (ed.). Plant breeding reviews. AVI Publ. Co., Westport, Conn.

Environment Canada. 2003. Canadian climate normals 1971-2000. 17 Nov. 2003. http://www. climat.meteo.ec.gc.ca/climate_normals/results_e.html. juvenile stage will be carried over when these
Friesen, L.J. and C. Stushnoff. 1989. Vegetative maturity of Amelanchier alnifolia Nutt. compared to red osier dogwood and rescue crabapple. Can. J. Plant Sci. 69:955-960.

Fuchigami, L.H., C.J. Weiser, K. Kobayashi, R. Timmis, and L.V. Gusta. 1982. Adegree growth stage (GS) model and cold acclimation in temperate woody plants, p. 93-116. In: P.H. Li and A. Sakai (eds.). Plant cold hardiness and freezing stress. vol. 2. Academic Press, New York.

Gelvonauskis, B., P. Duchovskis, and G. Bandaraviciene. 2000. Investigation of winter hardiness and cold hardiness in apple progenies. Acta Hort. 538:277-280.

Guak, S. and L.H. Fuchigami. 2001. Effects of applied ABA on growth cessation, bud dormancy, cold acclimation, leaf senescence and $\mathrm{N}$ mobilization in apple nursery plants. J. Hort. Sci. Biotechnol. 76: 459-464.

Gusta, L.V., M.J. Tyler, and T.H. Chen. 1983. Deep undercooling in woody taxa growing near the -40 ${ }^{\circ} \mathrm{C}$ isotherm. Plant Physiol. 72:122-128.

Hansche, P.E. 1983. Response to selection, p. 154-171. In: J.N. Moore and J. Janick (eds.). Methods in fruit breeding. Purdue Univ. Press, West Lafayette, Ind.

Holubowicz T. and J. Pieniazek. 1976. The effect of different temperatures on the hardening of Antonovka seedlings. Prace Komisji Nauk Rolniczch i Konusji Nauklesnych. 41:99-105.

Kadir, S.A. and E.L. Proebsting.1994. Screening sweet cherry selections for dormant floral bud hardiness. HortScience 29(2):104-106.

Ketchie, D.O. 1985. Cold resisatnce of apple trees through the year and its relationship to the physiological stages. Acta Hort. 168:131-137.

Lapins, K. 1962. Artificial freezing as a routine test of cold hardiness of young apple seedlings. Proc. Amer. Soc. Hort. Sci. 81:26-34.

Magness, J.R. 1929. Collar rot of apple trees. Washington Agr. Expt. Sta. Bul. 236.

Mathers, H. 1988. Screening Malus seedlings for cold resistance. MS. thesis. Univ. of Sask. Saskatoon, Sask.

Mathers, H.M., H.A. Quamme, and R.T. Brownlee. 1991. A procedure for converting an ultra-low temperature freezer for freezing biological material. Can. J. Plant Sci. 71:1281-1283.

Ontario Ministry of Agriculture andFood. 2001. Recommended apple varieties for Ontario-2001. Updated:02/20/2003. Lastaccessed: 11/17/2003. $<$ http://www.gov.on.ca/OMAFRA/english/ crops/facts/00aplrec.htm>.

Quamme, H.A. and C. Stushnoff, 1983. Resistance to environmental stress, p. 242-266. In: J. Moore and J. Janick (eds.). Methods in fruit breeding. Purdue Univ. Press, West LaFayette, Ind.

St. Pierre, R. 1995. The development of native fruit species as horticultural crops in Saskatchewan-An overview. Univ. of Sask. 17 Nov. 2003. http://www.ag.usask.ca/departments/plsc/ nfdp/infoexchane/dev.html.

Steel, R.G.D. and Torrie, J.H. 1980. Principles and procedures of statistics: A biometrical approach. McGraw-Hill Book Co., New York.

Strang, J.G. and C. Stushnoff. 1975. A classification of hardy North American apple cultivars based on hardiness zones. Fruit Var. J. 29:78-108.

Stushnoff, C., O. Junttila, and A. Kaurin. 1985. Genetics and breeding for cold hardiness in woody plants, p. 141-156. In: A. Kaurin, O. Junttila, and J. Nilsen (eds.). Plant production in the north Norwegian University Press, Oslo.

Stushnoff, C. and H.A. Quamme. 1983. Adaptation to specific climatic and soil environments, $p$ 267-271. In: J.N. Moore and J. Janick (eds.). Methods in fruit breeding. Purdue Univ. Press, West Lafayette, Ind. 